\title{
LITERAT URE
}




\section{BOOK REVIEWS}

Javaid Rehman, International Human Rights Law, 2nd Edition • London: Longman Publishing Group, 2010 • ISBN 978-1405811811 • 947 + lxvi pp

International human rights law is one of the fastest growing areas of international law. The book titled International Human rights law is the second edition of Professor Javaid Rehman and was released in 2010. This volume expands on his previous work of the first edition which was published in 2005 and reflects the contemporary conventional legal developments in this field. The author with his experience and expertise in this field has produced an excellent treatise in order to demonstrate the progress and development along the line of the judgements of national and international judiciaries and thereby emerging as one of the leading academics and commentator in this filed.

A glance of the contents, surprises the readers due to the range of development of international instruments as well as the classification of the sections of area of law. This endeavour is confined to five parts of 24 chapters in total. The entire contents represent systematic and methodological analysis. It gives readers general and depth information and guides them on how to explore more details whenever required of this ever growing area of law. The footnotes are immense and very useful for further research and exploring the jurisprudence.

Part one contains three chapters. The first chapter introduces and outlines the scope of the book, themes of international human rights law and structure of the analyses. It assures the readers in general and students, academics, legal and foreign policy practitioners in particular with confidence that this book can be considered as their text book for references and to perform their professional duty. The second chapter deals with definitions, sources of primary and secondary nature and explains how the concept and idea of international human rights have become jus cogens of international law, and therefore emphasising that state and non state actors have no option other than recognising them. The third chapter is inevitably very comprehensive and introduces the growth and expansion of international human rights law and outlines the sequences 
of emergences of institutions of the UNO and their role in promotion and protection of human rights. Functions and procedures of institutions are given for anyone using this book to direct them how to seek remedy from these institutions.

Part two, under the title of the international bill of rights contains three chapters and deals with the contemporary developments of international human rights instruments. The chapters systematically analyse the sequence of adoption of the instruments namely, the Universal Declaration of Human Rights [1948] International Covenant on Civil and Political Rights, and The International Covenant on Economic, Social and Cultural Rights [1966]. In these chapters, the author examines the international legal nature of these instruments and their entire aspects of procedure and mechanism which are created for the promotion and protection of international human rights. The contents of these chapters reflect the scrutiny and depth of the analyses of these legal instruments and demonstrate how the legal order of the international human rights has become an integral part of international law.

Part three of the book is allocated to dealing with the regional protection of human rights. History reflects that the atrocities were committed against humanity and humankind in different times, in different forms and in different parts of the world. Naturally, jurists, statesmen and victims have reacted by confronting the perpetrators and laid foundations for protection and to prevent repetition at least at regional level. Professor Rehman identifies the historical evolution of regional institutional arrangements for protection of human rights and focuses on them in five chapters. In this section, two chapters are allocated to cover the European Human Rights law and system. Comparatively, European human rights instruments and institutions have long history and could be considered as an advanced and well developed legal order for the protection of human rights at the regional level. It is therefore, more appropriate to cover the European system in two chapters which trace all relevant conventions, instruments and the legal mechanism established therein. The following two chapters deal with the inter-American system and the African system for the protection of human rights and their role in protecting human rights at the respective regional levels. The final chapter of this part explores the roots of human rights law in Islam and the role of the League of the Arab states in the promotion and protection of human rights, while commenting on human rights is- 
sues in the South Asian region. The chapters of this section demonstrate the striking feature of the absence of regional arrangements for Asia, thus raising questions in the search for the existence of this vacuum. Although for convenience "Asian solidarity" is advocated, formation of Asian human rights instrument and mechanism continue to remain a challenging target.

Part four contains eight chapters to deal with group rights which are generally referred as collective rights. Equality and non-discrimination which are the fundamental principles of international law have been analysed in the first chapter of this part and as the twelfth chapter in chronological order in the contents. In this chapter, the author traces the international attempts under the auspicious of the UNO to enforce and implement the principles of equality and non-discrimination. The author makes observations on the formation of the International Convention on the Elimination of All Forms of Racial Discrimination and its mechanism for international supervision on the implementation of the provisions of the Convention. The next chapter of this section is devoted for the rights of minorities on which the author could be regarded an accomplished expert. In another of his treatise, the author has commented that "minorities are extremely capable and successful in informing their sufferings to their sympathisers internationally." Along the line of his familiarity and acquaintances to the problems and continued suffering of minorities all over the world, he comprehensively outlines their international status and applicable international human rights law. In other chapters of this part, rights of peoples and indigenous peoples, rights of women, rights of the child, rights of persons with disabilities, rights of refugees and migrant workers and their families are analysed in an academic and professional manner.

The final part of the book is allocated to concentrate on the contemporary legal issues of international human rights. The author identifies international criminal court, the question of terrorism, international humanitarian law and enforced disappearances as the emerging international issues within the context of human rights law and treats them in each chapter respectively. The question of terrorism continues to be a controversial issue at national as well as international levels. The UNO has been unable to find a suitable definition for terrorism to date, while observing in one of its early days instruments the Universal Declaration of Human Rights that 
It is essential, if man is not to be compelled to have recourse, as a last resort, to rebellion against tyranny and oppression, that all human rights should be protected by the rule of law.

The author handles the issues of terrorism in balanced academic approach in the chapter and emphasises the need for utmost important to human security and respect for humanity.

The entire volume and its treatise demonstrate how international human rights have become an integral part of international law by way of law making procedures of the UNO and imposing onuses on state and nonstate actors to ratify those instruments. The international human rights regimes which are considered by the author, should remind the rulers of intolerant democracies that they cannot by pass the rights regimes of the UNO and they have no liberty to do so. Further, it is evidenced in the book that the author has endeavoured a substantial length of time to work on this project while demonstrating his sound knowledge in this area of law. It is not an exaggeration to mention that if this book is to be treated as a hand book for human rights handlers (officials) at national level and foreign policy practitioners, many human rights issues could be resolved amicably at national level.

Finally, the author sends a strong message [to leaders of states, academics human rights lawyers and diplomats] that state which is primary subject of international law, no longer entitled to govern its peoples and citizens as they please or at their discretion. Contrarily, they are obliged and duty bound to recognise and implement the rights regimes at national level and subjected to international scrutiny. Any systematic and serious violations of human rights cannot be sheltered under the pretext of sovereignty and territorial integrity. In short, the author relying on customary and conventional rights regimes concludes that state sovereignty is conditional and entitlement to sovereign power is upon fulfilling certain criterion including human rights norms. The era of absolute sovereignty has demised. Sovereignty is not a defence for violation of human rights and denial of justice.

SANDrasegaram PARAMALINGAM 